\title{
Surfactant protein B and RAGE increases in the plasma during cardiopulmonary bypass: a pilot study
}

\author{
P. Agostoni*,\#, C. Banfi*, ${ }^{*}$, M. Brioschi*, , D. Magrì ${ }^{+}$, S. Sciomer ${ }^{\S}$, G. Berna*, \\ C. Brambillasca*, G. Marenzi* and E. Sisillo*
}

ABSTRACT: Surfactant derived protein B (SPB) and plasma receptor for advanced glycation end products (RAGE) have been proposed as markers of lung injury. The former is produced specifically by pneumocytes while RAGE production is present in several body tissues. Cardiopulmonary bypass (CPB) generates a transient lung injury. We measured SPB and RAGE in plasma before surgery and after CPB, as well as $24 \mathrm{~h}$ and $48 \mathrm{~h}$ later.

We analysed plasma samples from 20 subjects scheduled for elective coronary artery bypass grafting. We performed a quantitative analysis of plasma levels of RAGE and SPB mature form $(8 \mathrm{kDa})$ by ELISA and a semi-quantitative analysis of SPB immature form ( $40 \mathrm{kDa})$ by Western blotting.

Surgery procedures were uneventful. After CPB RAGE median (75th-25th interquartile difference) increased from $633(539) \mathrm{pg} \cdot \mathrm{mL}^{-1}$ to $1,362(557) \mathrm{pg} \cdot \mathrm{mL}^{-1}(\mathrm{p}<0.01)$, while mature SPB increased from $5,587(3,089) \mathrm{ng} \cdot \mathrm{mL}^{-1}$ to $20,307(19,873) \mathrm{ng} \cdot \mathrm{mL}^{-1}(\mathbf{p}<0.01)$. RAGE and mature SPB returned to normal values within $48 \mathrm{~h}$. This behaviour was confirmed when RAGE and SPB were normalised for protein content. Parallel changes were observed for immature SPB.

Plasma RAGE and SPBs are sensitive and rapid markers of lung distress.

KEYWORDS: Gas diffusion, heart failure, lung injury, surfactant

$\mathbf{P}$

ulmonary surfactant is a membrane-based, lipid-protein complex with surface-active characteristics $[1,2]$. The protein component, accounting for $\sim 10 \%$ of the total pulmonary surfactant, is synthesised only by type II pneumocytes of the alveolar epithelium. Surfactant proteins are responsible for several innate defence mechanisms and have a key role in stabilising the surfactant itself, contributing to maintain normal pulmonary biophysics [3-5]. The surfactant protein type B (SPB) is one of the four surfactant proteins and its specific function is to stabilise the alveolar surfactant $[6,7]$. SPB is produced in the alveolar cell as an immature $\sim 40 \mathrm{kDa}$ form and undergoes complex proteolytic processes inside the type II pneumocytes, which leads through intermediate SPB precursors weighing $\sim 24 \mathrm{kDa}$ and $\sim 17 \mathrm{kDa}$ to the $\sim 8 \mathrm{kDa}$ SPB mature and active form $[8,9]$. The latter is secreted into the alveolar space [9]. SPB has a relevant gradient across the alveolar-capillary membrane so that, under physiological conditions, only a low concentration of SPB is found in the blood. Vice versa, in case of alveolar-capillary membrane damage a higher level of SPB is detected in the blood stream.
Indeed, a high level of plasma SPB, either the mature or the immature forms, has been reported in acute pulmonary oedema [10], acute respiratory distress syndrome [11, 12] and chronic heart failure (CHF) [13, 14].

Lung function abnormalities are part of the CHF syndrome, being both lung mechanics and gas exchange impaired [15-17]. Recently, increased circulating plasma SPB values in patients with CHF have been observed [13, 14]. MAGRI et al. [13] specifically showed a correlation between SPB and lung diffusion abnormalities, suggesting this protein as a possible biological marker of alveolarcapillary barrier damage. Moreover, other researchers hypothesised that an acute increase in pulmonary vascular pressure, caused by exerciseinduced myocardial dysfunction, may result in an augmented SPB leakage from the alveoli into the circulation due to integrity loss of the alveolarcapillary barrier to protein $[10,14,18]$. Notably, in $\mathrm{CHF}$ patients, lung diffusion capacity is reduced after exercise [19].

Plasma receptor for advanced glycation end products (RAGE) is a member of the immunoglobulin
AFFILIATIONS

*Centro Cardiologico Monzino, IRCCS, Dept of Cardiovascular Sciences, University of Milan,

"Dept of Pharmacological Sciences, University of Milan, Milan,

${ }^{+}$Dipartimento di Scienze Cliniche e Molecolari, Università "La Sapienza", and

${ }^{\S}$ Dipartimento di Scienze Cardiovascolari, Respiratorie e Morfologiche, Università "La Sapienza", Rome, Italy. "Division of Critical Care and Respiratory Medicine, Dept of Medicine, University of Washington, Seattle, WA, USA.

CORRESPONDENCE

P. Agostoni

Centro Cardiologico Monzino IRCCS Via Parea 4

20138 Milan

Italy

E-mail: piergiuseppe.agostoni@ ccfm.it

Received:

March 232010

Accepted after revision:

July 022010

First published online:

July 222010 
superfamily that acts as a progression factor amplifying the immune and inflammatory response in several pathophysiological conditions, including lung disease [20]. During lung injury RAGE may be secreted into the alveolar space and into the blood [21] and, although RAGE may be secreted by several tissues, it has been proposed as a strong prognostic marker of lung disease [22].

In patients undergoing cardiac surgery, cardiopulmonary bypass (CPB) may generate lung dysfunction which is an important factor of morbidity and mortality [23-25]. It has been suggested that neutrophil activation during extracorporeal circulation and during lung reperfusion leads to a significant release of inflammatory mediators [24-26] with a consequential increase in pulmonary vascular permeability and endothelial cell damage $[27,28]$, both possibly reflected in an increase in plasma SPB and RAGE levels. Furthermore, the required mechanical ventilation, although time-limited, might represent per se a cause of acute lung injury [12]. We used CPB and mechanical ventilation, required during coronary artery bypass grafting ( $\mathrm{CABG}$ ) surgery, as a tool to investigate the correlation between acute lung distress, RAGE and SPB in the blood stream. To our knowledge, no attempts have been made to evaluate the possible relationship between plasma RAGE and SPB levels and the CPB-induced lung distress. Indeed SPB, being uniquely produced in the type II pneumocytes, might become a useful tool to predict post-surgical respiratory outcome or, more generally, SPB may become an index of lung injury.

This pilot study was therefore designed to compare the behaviour of circulating plasma SPB levels with RAGE in patients undergoing $\mathrm{CPB}$ and mechanical ventilation during CABG. We measured SPB both as the large precursor of $\sim 40 \mathrm{kDa}$, the heaviest of the so-called immature forms, and as the mature and active form weighing $\sim 8 \mathrm{kDa}$. This enabled us to compare, as much as possible, our results with previous reported data. Moreover, we measured the SPB mature $(\sim 8 \mathrm{kDa})$ form in order to have a quantitative SPB measurement and the SPB immature form $(\sim 40 \mathrm{kDa})$ which, at present, can be measured only semi-quantitatively by Western blotting analysis, to evaluate the possibility that lung abnormalities only consist of an exaggerated production of mature SPB with an abnormal SPB absorption. Indeed, presence in the blood of the immature SPB, which physiologically is only located inside alveolar type II cells suggests alveolar cell damage.

\section{METHODS}

\section{Study population}

20 subjects scheduled for elective CABG procedure were consecutively enrolled in the study. Study inclusion criteria were stable clinical conditions for at least 2 months and absence of clinical history and/or documentation of heart failure: pulmonary embolism or primary valvular heart disease; pericardial disease; chronic bronchitis; primitive or occupational lung disease; anaemia (haemoglobin $<11 \mathrm{~g} \cdot \mathrm{dL}^{-1}$ ); renal insufficiency (serum creatinine $>2.0 \mathrm{mg} \cdot \mathrm{dL}^{-1}$ ); and significant peripheral vascular disease. Perioperatory risk was assessed by EuroSCORE [29]. All patients underwent standard echocardiographic pre-surgical evaluation. During the surgical procedure all patients underwent routine haemodynamic, ventilatory and blood gases surveillance. Red blood cell count, serum creatinine and lactate dehydrogenase (LDH) were also measured before surgery and $24 \mathrm{~h}$ and $48 \mathrm{~h}$ later. Blood samples for SPBs determination were taken before surgery, after CPB and $24 \mathrm{~h}$ and $48 \mathrm{~h}$ later.

The investigation was approved by the scientific and local ethics committee of Centro Cardiologico Monzino IRCCS (Milan, Italy) and subjects signed a written informed consent before participating in the study. The authors had full access to and take full responsibility for the integrity of the data. All authors have read and agree to the manuscript as written.

\section{Specimen handling and assays}

Fresh blood $(5 \mathrm{~mL})$ was drawn into Vacutainer tubes containing citrate $0.129 \mathrm{~mol} \cdot \mathrm{L}^{-1}$ as an anticoagulant. Plasma was immediately prepared by means of centrifugation at 1,500 $\times \mathrm{g}$ for $10 \mathrm{~min}$ at $4^{\circ} \mathrm{C}$, divided into aliquots and frozen at $-80^{\circ} \mathrm{C}$ until assayed.

The analysis of the immature form of SPB ( $40 \mathrm{kDa})$ was performed by Western blotting on plasma samples, as previously described [13]. Briefly, in order to precisely resolve low-molecular weight proteins, equal amounts of plasma proteins $(50 \mu \mathrm{g})$ were separated by one dimensional SDSPAGE on $15 \%$ polyacrylamide gels using a Tris-Tricine buffer system in nonreducing conditions [30]. The protein concentration was evaluated by the method of BRADFORD [31]. Gels were electrophoretically transferred to nitrocellulose at $60 \mathrm{~V}$ for $2 \mathrm{~h}$. Immunoblotting on transferred samples was performed as follows: blocking in 5\% (weight/volume) non-fat milk in Trisbuffered saline $\left(100 \mathrm{mmol} \cdot \mathrm{L}^{-1}\right.$ Tris- $\mathrm{HCl}, \mathrm{pH} 7.5,150 \mathrm{mmol} \cdot \mathrm{L}^{-1}$ $\mathrm{NaCl}$ ) containing $0.1 \%$ Tween 20 (TBS-T) for $1 \mathrm{~h}$ at room temperature; overnight incubation at $4{ }^{\circ} \mathrm{C}$ with primary antibody against SPB (rabbit anti-human SPB H300; Santa Cruz Biotechnology, Santa Cruz, CA, USA) diluted at 1:200 in 5\% $(\mathrm{w} / \mathrm{v})$ non-fat milk in TBS-T; incubation with secondary goat anti-rabbit antibody conjugated to horseradish peroxidase (Bio-Rad, Milan, Italy) at 1:1,000 for $1 \mathrm{~h}$. Bands were visualised by enhanced chemiluminescence using the ECL kit (GE Healthcare, Milan, Italy) and acquired by a densitometer (GS800; Bio-Rad). Bands at $40 \mathrm{kDa}$ detected by ECL were quantified by densitometry of exposed film using image analysis software (QuantityOne version 4.5.2; Bio-Rad). Following transfer membranes were stained with MemCode $^{\mathrm{TM}}$ reversible protein stain (Pierce Biotechnology, Cramlington, UK) according to the manufacturer's instructions to ensure equivalent loading of protein. For each subject, data are reported as the ratio of band volume after CPB $(24 \mathrm{~h}$ after and $48 \mathrm{~h}$ ) after versus the volume of the sample before surgery after local background subtraction and are expressed as arbitrary units (AU). Interassay coefficient of variation was $12.1 \pm 2.9 \%$. The quantitative analysis of the levels of the mature form $(8 \mathrm{kDa})$ of SPB was performed by an ELISA purchased from Uscn Life Science Inc. (Wuhan, China). Briefly, the microtitre plate provided in this kit was pre-coated with an antibody specific to the mature SPB. Standards or samples were added to the microtitre plate wells followed by incubation with a biotin-conjugated polyclonal antibody specific for SPB. Avidin conjugated to horseradish peroxidase was then added to each microplate well. Following this, a tetramethylbenzide substrate solution was added to each well and the enzyme-substrate reaction terminated by the addition of a 
sulfuric acid solution. The absorbance (optical density (OD)) was measured spectrophotometrically at a wavelength of $450 \mathrm{~nm}$ on a microplate reader (Mithras LB 940; Berthold Technologies $\mathrm{GmbH}$ and Co. KG, Bad Wildbad, Germany). The concentration of SPB in the samples was then determined by comparing the OD of the samples to the standard curve and expressed as SPB $\mathrm{ng} \cdot \mathrm{mL}^{-1}$ or SPB $\mathrm{ng} \cdot \mathrm{mg}^{-1}$ protein. Limit of sensitivity was $1.95 \mathrm{ng} \cdot \mathrm{mL}^{-1}$. Interassay coefficient of variation was $11.6 \pm 2.1 \%$. Intra-assay coefficient of variation was $7.9 \pm 1.5 \%$.

Plasma RAGE levels were determined using a commercially available ELISA kit (R\&D Systems, Minneapolis, MN, USA) according to the manufacturer's protocol. Measurements were performed in duplicate and the results were averaged. The intra-assay and interassay coefficients of variation were $<6 \%$ and $<8 \%$, respectively.

\section{Perioperative management}

Patients received routine cardiac medication, except for antiplatelet drugs, until the day of surgery. Pre-medication consisted of morphine $\left(0.1 \mathrm{mg} \cdot \mathrm{kg}^{-1}\right.$ i.m. $)$ and atropine $(0.05$ $\mathrm{mg} \cdot \mathrm{kg}^{-1}$ i.m.) $1 \mathrm{~h}$ before surgery. A prophylactic intravenous antibiotic (cefazoline, 2 g every $8 \mathrm{~h}$ during the first $24 \mathrm{~h}$ ) was given after the positioning of a venous access. Anaesthesia was induced with thiopental $\left(4-6 \mathrm{mg} \cdot \mathrm{kg}^{-1}\right)$, sufentanil $\left(1 \mu \mathrm{g} \cdot \mathrm{kg}^{-1}\right)$ and succinilcholine $\left(1 \mathrm{mg} \cdot \mathrm{kg}^{-1}\right)$ and maintained with inhaled sevorane and incremental doses of pancuronium to facilitate muscle relaxation. Patients were monitored with five-lead electrocardiogram, central venous catheter, radial artery line, Foley catheter and nasopharyngeal and rectal temperature probes. Traditional surgical procedures were used to position the CPB circuits. Non-pulsatile CPB was conducted in moderate hypothermia $\left(34^{\circ} \mathrm{C}\right)$, using roller pump with a membrane oxygenator and a micron arterial filter. The circuit was primed with $1 \mathrm{~L}$ of Normosol $\mathrm{R}_{\varpi}, 500 \mathrm{~mL}$ of $5 \%$ glucose, $100 \mathrm{~mL}$ of $18 \%$ sodium bicarbonate solution, and $100 \mathrm{~mL}$ bolus of $18 \%$ mannitol was administered just before the opening of aortic cross clamp. The flow rate, always $>2.4 \mathrm{~L} \cdot \mathrm{min}^{-1} \cdot \mathrm{m}^{-2}$, was titrated to ensure a mean arterial pressure between 55 and $80 \mathrm{mmHg}$ and norepinephrine was injected when necessary. If needed, additional Ringer's lactate solution was added into the venous reservoir. Haemodilution up to a minimum haemoglobin concentration of $7 \mathrm{~g} \cdot \mathrm{dL}^{-1}$ was allowed. Myocardial protection was achieved by means of intermittent anterograde and retrograde cold blood cardioplegia. After weaning from $\mathrm{CPB}$ the entire content of the circuit was collected and slowly returned to the patient.

During surgery patients were ventilated with intermittent positive pressure ventilation at positive end-expiratory pressure (PEEP) $0 \mathrm{cmH}_{2} \mathrm{O}$ with $8 \mathrm{~mL} \cdot \mathrm{kg}^{-1}$ of tidal volume, a respiratory frequency of $13 \mathrm{breath} \cdot \mathrm{min}^{-1}$ and an inspiratory/ expiratory ratio of $1: 2$. The inspiratory oxygen fraction $\left(F \mathrm{I}, \mathrm{O}_{2}\right)$ started with 1 and was thereafter reduced to the lowest value which maintains oxygen saturation $\left(\mathrm{Sa}_{2} \mathrm{O}_{2}\right)$ higher than $95 \%$. During surgery tidal volume, respiratory frequency and $\mathrm{FI}, \mathrm{O}_{2}$ were adjusted to maintain a carbon dioxide tension of $\sim 35 \mathrm{mmHg}$. After weaning from $\mathrm{CPB}$, mechanical ventilation was resumed with the same parameters but with $5 \mathrm{cmH}_{2} \mathrm{O}$ of PEEP. After surgery, patients were transferred to the intensive care unit, still sedated and intubated; propofol was used for sedation until complete rewarming. Patients were ventilated in intermittent positive pressure ventilation with tidal volume, respiratory frequency and $\mathrm{F} \mathrm{I}_{1} \mathrm{O}_{2}$ adjusted to maintain normocapnia and $\mathrm{Sa}_{2} \mathrm{O}_{2}>95 \%$ until the beginning of the weaning protocol. Weaning started when the following conditions were reached: haemodynamic stability (low doses of inotropic drugs allowed), no major recurrent cardiac arrhythmia, no surgical bleeding and patients awake and fully rewarmed. Patients were weaned from mechanical ventilation through a cycle of pressure support ventilation. In intensive care, following the on-duty physician's decision, temporary intravenous vasodilating agents (nitroglycerine) in three cases, vasocostrictors (noradrenaline) in two cases and positive inotropic agents in five cases (dopamine/dobutamine) were used. Haemodynamic and gas exchange parameters recorded during surgery and in the two following days are reported in table 1 .

\section{Statistical analysis}

Normally distributed variables are expressed as mean \pm SD and the differences between groups were analysed by ANOVA followed by paired t-tests where necessary. Categorical variables were analysed with the Chi-squared test. Data with skewed distribution are presented as median and interquartile range difference (75th-25th). RAGE measurements, albeit normally distributed, are presented as median and interquartile range difference ( 75 th-25th) to provide a more immediate comparison with SPB values. Wilcoxon test was used to compare the not normally distributed data. Moreover, because plasma SPB values showed a nonlinear distribution, Spearman correlation was used to disclose possible correlations between these proteins and clinical, echocardiographic and laboratory data. A p-value $<0.05$ was considered statistically significant. All tests were two-sided. All data were evaluated with the database SPSS-PC+ (SPSS Inc., Chicago, IL, USA).

\section{RESULTS}

General characteristics of the study population, including CPB and mechanical ventilation time are reported in table 2 . Seven patients had diabetes mellitus and 10 had systemic hypertension. Previous cardiac surgery had been performed in four cases. Treatment included angiotensin-converting enzyme inhibitors in 10 cases, diuretics in seven cases, $\beta$-blockers in

\begin{tabular}{|c|c|c|c|c|c|}
\hline Variables & $\begin{array}{l}\text { Before } \\
\text { surgery }\end{array}$ & After CPB & After $24 \mathrm{~h}$ & After $48 \mathrm{~h}$ & ANOVA \\
\hline HR beats $\cdot \mathrm{min}^{-1}$ & $77.9 \pm 10.9$ & $80.7 \pm 12$ & $87.6 \pm 14.7$ & $83.9 \pm 15.6$ & NS \\
\hline Pas $\mathrm{mmHg}$ & $157 \pm 28$ & $94 \pm 22^{\# \#}$ & $119 \pm 23^{* *, \cdot 9}$ & $117 \pm 18^{++, \S \S}$ & $p<0.001$ \\
\hline$P$ ad $\mathrm{mmHg}$ & $77 \pm 9$ & $62 \pm 16^{\# \#}$ & $54 \pm 10^{\star \star}$ & $55 \pm 9^{++}$ & $p<0.001$ \\
\hline $\mathrm{Pa}, \mathrm{O}_{2} \mathrm{mmHg}$ & & $242 \pm 26$ & $92 \pm 6^{\circ}$ & $82 \pm 7^{\S \S}$ & $p<0.001$ \\
\hline $\mathrm{Fl}, \mathrm{O}_{2}$ & Room air & 1 & Room air & Room air & \\
\hline
\end{tabular}

Data are presented as mean \pm SD, unless otherwise stated. CPB: cardiopulmonary bypass; HR: heart rate; Pas: systolic blood pressure; Pad: diastolic blood pressure; $\mathrm{Pa}, \mathrm{O}_{2}$ : arterial oxygen tension; $\mathrm{Fl}, \mathrm{O}_{2}$ : inspiratory oxygen fraction; NS: nonsignificant. ${ }^{\# \#}: \mathrm{p}<0.01$ after CPB versus before surgery; ${ }^{* *}: \mathrm{p}<0.01$ after $24 \mathrm{~h}$ versus before surgery; ${ }^{~} \uparrow: p<0.01$ after $24 \mathrm{~h}$ versus after CPB; ${ }^{++}: p<0.01$ after $48 \mathrm{~h}$ versus before surgery; ${ }^{\S \S}: \mathrm{p}<0.01$ after $48 \mathrm{~h}$ versus after CPB. 


\begin{tabular}{lc} 
TABLE 2 & General characteristics of the study population \\
Age $\mathbf{y r s}$ & $65 \pm 9$ \\
Males & $17(85)$ \\
BMI $\mathbf{~ k g} \cdot \mathbf{m}^{-2}$ & $27 \pm 4$ \\
LVEF \% & $52 \pm 10$ \\
Smoke habit actual/previous/never-smoker $\mathbf{n}$ & $4 / 7 / 9$ \\
Serum creatinine $\mathbf{~} \mathbf{g} \cdot \mathbf{d L}^{-1}$ & $1.0 \pm 0.3$ \\
CPB time $\mathbf{m i n}$ & $103 \pm 28$ \\
Intubation time $\mathbf{m i n}$ & $582 \pm 106$ \\
\hline
\end{tabular}

Data are presented as mean \pm SD or as $n(\%)$, unless otherwise stated. BMI: body mass index; LVEF: left ventricular ejection fraction; CPB: cardiopulmonary bypass.

14 cases, calcium channel blockers in three cases and nitrates in seven cases. The CPB was performed in $<3 \mathrm{~h}$ (range $71-$ 169) min. Patients were free from heart failure as shown by their history and average normal left ventricular ejection fraction; only two subjects had a left ventricular ejection fraction between 35 and $40 \%$. EuroSCORE was also low $(3.5 \pm 1.9)$. In no cases were further surgical procedures needed for bleeding or other reasons. CPB was associated with a significant haemoglobin reduction due to blood loss and/or blood dilution (table 3). $24 \mathrm{~h}$ after surgery white blood cell count and LDH were increased (table 3).

Mature SPB ( $\sim 8 \mathrm{kDa})$ plasma concentration before surgery, immediately after CPB and $24 \mathrm{~h}$ and $48 \mathrm{~h}$ later is reported in table 3 and figure 1 , both as absolute values $\left(\mathrm{ng} \cdot \mathrm{mL}^{-1}\right.$ ) and as normalised values corrected for total protein concentration (ng $\cdot \mathrm{mg}^{-1}$ total proteins). The latter was needed because during CPB total plasma protein concentration dramatically decreased (table 3). A four- to five-fold increase of mature SPB was observed immediately after CPB which was almost recovered in $24 \mathrm{~h}$ and totally normalised within $48 \mathrm{~h}$.
The immature SPB form $(\sim 40 \mathrm{kDa})$ cannot be precisely measured because Western blotting allows only a semiquantitative analysis and, moreover, only AU can be used. The ratios from pre-surgery increased similarly to mature SPB (table 3, fig. 2).

RAGE plasma concentration before surgery, immediately after $\mathrm{CPB}, 24 \mathrm{~h}$ and $48 \mathrm{~h}$ later is reported in table 3 and figure 3 both as absolute values $\left(\mathrm{pg} \cdot \mathrm{mL}^{-1}\right)$ and as normalised values corrected for total protein concentration $\left(\mathrm{pg} \cdot \mathrm{mg}^{-1}\right)$.

No correlation was found between $\mathrm{CPB}$ duration, $\mathrm{Pa}, \mathrm{O}_{2} / \mathrm{FI}, \mathrm{O}_{2}$ ratio and absolute LDH values and SPB and RAGE absolute values or changes. A weak linear correlation was found between highest LDH increase and the highest increase of mature SPB normalised for dilution $(\mathrm{r}=0.436, \mathrm{p}<0.05)$. This correlation did not reach statistical significance when absolute mature SPB values were considered $(r=0.377 ; p=0.06)$ and was totally absent if immature SPB was considered. No correlation was found between RAGE and SPB mature form before surgery. In contrast, a strong correlation $(\mathrm{r}=0.66, \mathrm{p}<0.001$ and $r=0.75, p<0.0001$ ) was found between SPB mature form and RAGE increases from before surgery to immediately after $\mathrm{CPB}$, both as absolute and protein normalised values, respectively.

\section{DISCUSSION}

This study shows that CPB is associated with an acute four- to five-fold increase in mature SPB, a 1.5-fold increase in the SPB immature form and a two-fold increase in RAGE. At $24 \mathrm{~h}$ RAGE and both SPB forms are significantly reduced and return to normal values within $48 \mathrm{~h}$.

RAGE has been shown to be a marker of lung injury and specifically of type I pneumocytes injury [32]. Moreover, RAGE has been recently proposed as a plasma marker of poor prognosis in patients ventilated with high tidal volume [22] or post-lung transplantation [33]. However, RAGE is expressed

\begin{tabular}{|c|c|c|c|c|c|}
\hline Variables & Before surgery & After CPB & After $24 \mathrm{~h}$ & After $48 \mathrm{~h}$ & ANOVA \\
\hline $\mathrm{Hb} \mathrm{mg} \cdot \mathrm{dL}^{-1}$ & $13.8 \pm 1.6$ & & $9.8 \pm 1.6^{* *}$ & $9.5 \pm 1.3^{++}$ & $p<0.001$ \\
\hline Hct \% & $39 \pm 5$ & & $27 \pm 5^{\star \star}$ & $27 \pm 4^{++}$ & $p<0.001$ \\
\hline WBC $u \cdot 10^{9} \cdot \mathrm{L}^{-1}$ & $7.3 \pm 1.4$ & & $10.9 \pm 2.8^{* *}$ & $11.9 \pm 3.7^{++}$ & $p<0.001$ \\
\hline $\mathrm{LDH} \mathbf{m g} \cdot \mathrm{dL}^{-1}$ & $232 \pm 130$ & & $364 \pm 171^{\star \star}$ & $347 \pm 175^{++}$ & $p<0.001$ \\
\hline SPB $40 \mathrm{kDa}$ ratio & 1 & $1.63(2.4)^{\# \#}$ & $1.58(2.2)^{\star *}$ & $1.01(0.66)^{\S \S, f f}$ & \\
\hline SPB $8 \mathrm{kDa} \mathrm{ng} \cdot \mathrm{mL}^{-1}$ & 5587 (3089) & $20307(19873)^{\# \#}$ & $6154(5788)^{\pi}$ & $4810(3340)^{\S \S, f f}$ & \\
\hline $\mathrm{SPB}_{\mathrm{N}} 8 \mathrm{kDa} \mathrm{ng} \cdot \mathrm{mg}^{-1}$ & $112(62)$ & $644(758)^{\# \#}$ & $184(103)^{\star \star *}, \cdot$ & $125(66)^{\S \varsigma, f f}$ & \\
\hline $\mathrm{RAGE} \mathrm{pg} \cdot \mathrm{mL}^{-1}$ & $633(575)$ & $1361(216)^{\# \#}$ & $508(216)^{* *,}, 9$ & $417(247)^{++, \$ \S_{.} f f}$ & \\
\hline
\end{tabular}

Data are presented as mean \pm SD or as median (75th-25th interquartile difference), unless otherwise stated. Hb: haemoglobin; Hct: haematocrit; WBC: white blood cell; LDH: lactate dehydrogenase; SPB $_{\mathrm{N}}$ : SPB normalised for total protein amount; RAGE $\mathrm{N}$ : RAGE normalised for total protein amount. ${ }^{\# \#: ~} \mathrm{p}<0.01$ after $\mathrm{CPB}$ versus before surgery; ${ }^{* \star}: p<0.01$ after 24 h versus before surgery; ${ }^{\mu}{ }^{\top}: p<0.01$ after 24 h versus after $C P B ;{ }^{++}: p<0.01$ after 48 h versus before surgery; ${ }^{\S \S}: p<0.01$ after 48 h versus after CPB; ${ }^{f f}: \mathrm{p}<0.01$ after $48 \mathrm{~h}$ versus after $24 \mathrm{~h}$. 

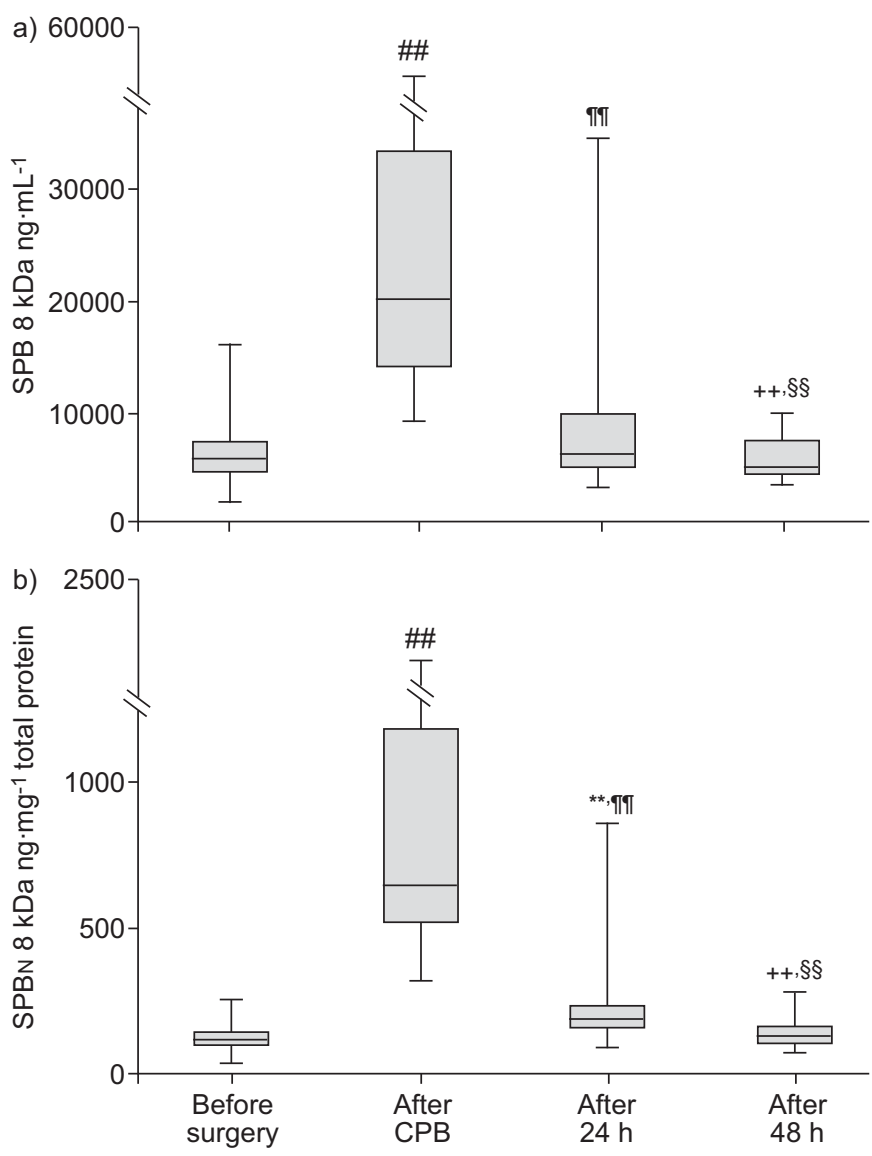

FIGURE 1. ELISA measurement of mature surfactant protein B (SPB) isoform in the plasma before surgery, immediately after cardiopulmonary bypass (CPB) and $24 \mathrm{~h}$ and $48 \mathrm{~h}$ after coronary artery bypass grafting. a) Data are expressed as $\mathrm{ng} \cdot \mathrm{mL}^{-1}$ of SPB at different time-points. b) Data are expressed as $\mathrm{ng} \cdot \mathrm{mg}^{-1}$ protein after correction for total protein concentration. Data are presented as median, 25th and 75th percentile range and minimum and maximal values. SPB $B_{N}$ SPB normalised for total protein amount. ${ }^{\# \#: ~} p<0.01$ after CPB versus before surgery; ${ }^{* *}: p<0.01$ after 24 h versus before surgery; ${ }^{~}{ }^{*}: p<0.01$ after 24 h versus after CPB; ${ }^{++}: \mathrm{p}<0.01$ after $48 \mathrm{~h}$ versus after CPB; ${ }^{\S \S}: \mathrm{p}<0.01$ after $48 \mathrm{~h}$ versus after $24 \mathrm{~h}$.

on multiple cell types, from vascular to inflammatory cells, such as smooth muscle cells, monocytes/macrophages, Tlymphocytes, dendritic cells, glomerular epithelial cells, to podocytes, cardiomyocytes and neurons (central and peripheral nervous systems) $[34,35]$. Thus, it is not surprising that the biology of RAGE impacts several biological and pathological settings. In contrast SPB is selectively produced by the type II pneumocytes.

Previously, immature and mature forms of SPB have been measured, usually in fluids obtained by bronchoalveolar lavage, by different methods and have been reported with different units [11, 12, 14, 18, 36]. Very few data are available for plasma levels of immature SPB [14, 18]. We analysed immature SPB by Western blotting analysis which allows only a semi-quantitative evaluation. Therefore, we cannot compare our results with those of previous studies. Mature SPB form has been measured by ELISA which allows a quantitative analysis. Our results are comparable with those reported by Doyle et al. [12] and De PAsQuale et al. [18].
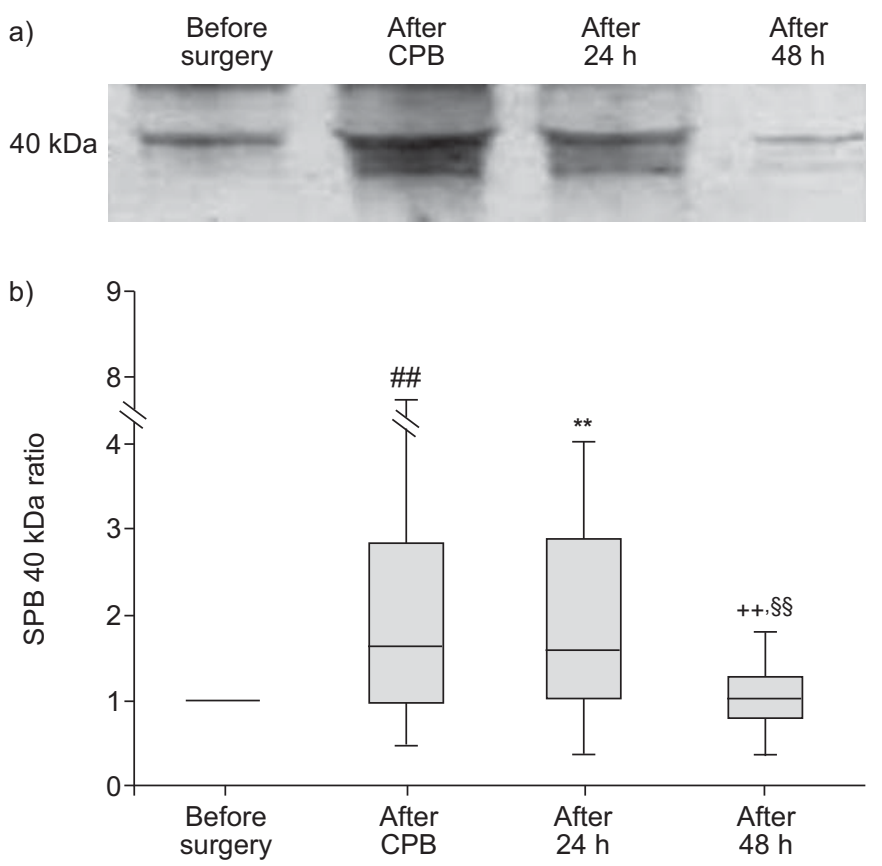

FIGURE 2. Immature surfactant protein B (SPB) levels in the plasma before surgery, immediately after cardiopulmonary bypass (CPB) and $24 \mathrm{~h}$ and $48 \mathrm{~h}$ after coronary artery bypass grafting. a) Representative Western blotting of immature SPB. b) Densitometric analysis of immature SPB expressed as the ratio of the SPB level at each time-point before surgery. Data are median, 25th and 75th percentile range and minimum and maximal values. ${ }^{\# \#: ~} p<0.01$ after $\mathrm{CPB}$ versus before surgery; ${ }^{* *}: p<0.01$ after $24 \mathrm{~h}$ versus before surgery; ${ }^{++}: \mathrm{p}<0.01$ after $48 \mathrm{~h}$ versus after CPB. ${ }^{\S s}: \mathrm{p}<0.01$ after $48 \mathrm{~h}$ versus after $24 \mathrm{~h}$.

Our population consisted of patients undergoing CABG in the absence of relevant comorbidities and, particularly, of known lung disease. Therefore, we cannot say if the SPB or RAGE changes would have been the same in the presence of previous lung diseases. We utilised $\mathrm{CPB}$ and mechanical ventilation, both needed because of CABG, as a tool to induce some acute lung distress if not injury. Some previous studies have demonstrated an increase in endotracheal SPB in children undergoing $\mathrm{CPB}$ [36], while others did not [37]. Indeed, clinically relevant lung impairment is rarely observed after CABG if surgery is performed in subjects free of relevant lung and cardiac comorbidities, as our patients were [23, 25]. We cannot say, however, if $\mathrm{CPB}$, mechanical ventilation or a combination of both, was needed for the observed SPB changes to take place. We did not identify any correlation between CPB or mechanical ventilation duration and SPB changes. However, our population was small and we had no patient with prolonged surgical procedures or need of long lasting mechanical ventilation.

The parallel behaviour of RAGE and SPB and the strong correlation between RAGE and SPB mature form changes are impressive and reinforce the concepts that SPB can be used as a plasma marker of lung injury. Indeed, although RAGE has been suggested as marker of lung injury [21] its almost ubiquitous production made the association between elevated RAGE and lung injury potentially questionable. SPB, however, is only produced in the lung. 

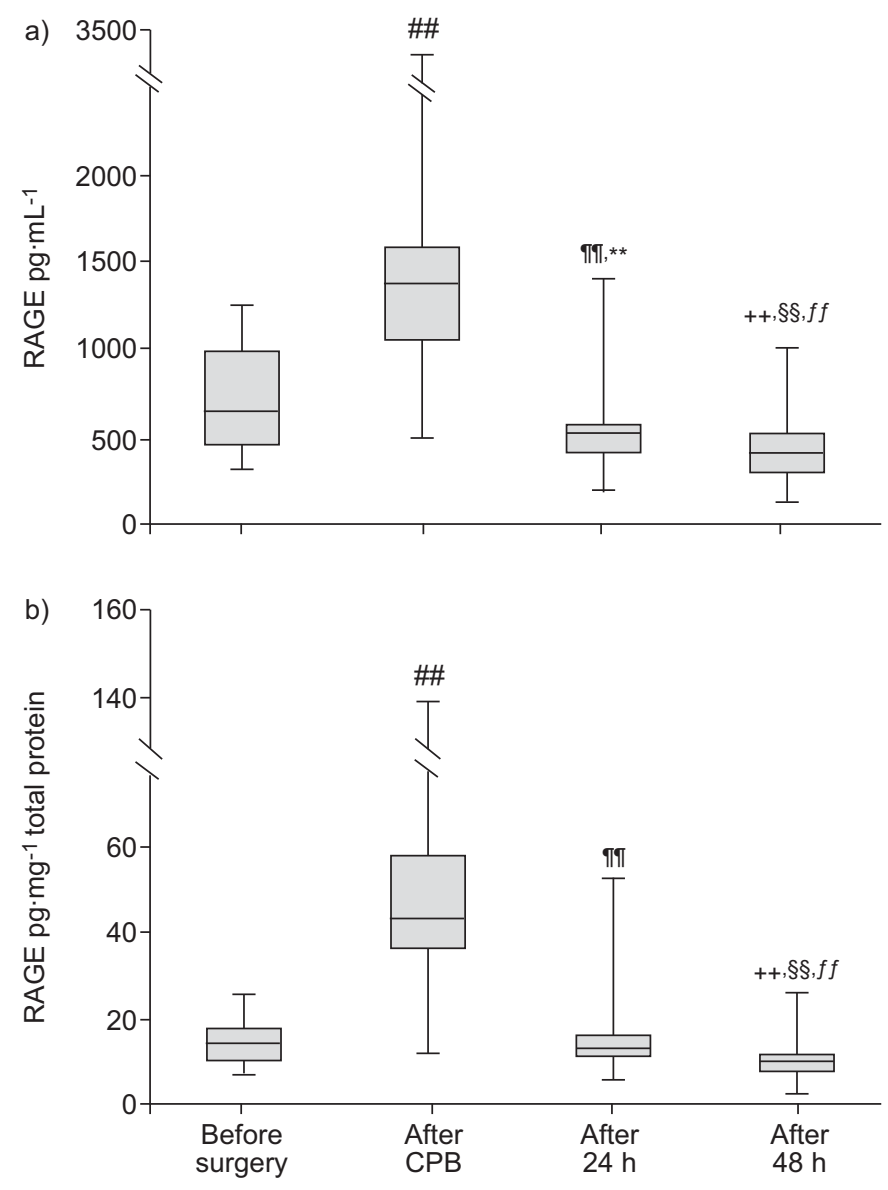

FIGURE 3. ELISA measurement of plasma receptor for advanced glycation end products (RAGE) in the plasma before surgery, immediately after cardiopulmonary bypass (CPB) and $24 \mathrm{~h}$ and $48 \mathrm{~h}$ after coronary artery bypass grafting. a) Data are expressed as $\mathrm{ng} \cdot \mathrm{mL}^{-1}$ of RAGE at different time-points. b) Data are expressed as $\mathrm{ng} \cdot \mathrm{mg}^{-1}$ proteins after correction for total protein concentration. Data are median, 25th and 75th percentile range and minimum and maximal values. \#\#: $p<0.01$ after CPB versus before surgery; ${ }^{* \star}: p<0.01$ after $24 \mathrm{~h}$ versus before surgery; ${ }^{"}: p<0.01$ after $24 \mathrm{~h}$ versus after CPB; ${ }^{++}: p<0.01$ after $48 \mathrm{~h}$ versus before surgery; ${ }^{\S \S}: p<0.01$ after 48 h versus after CPB; ${ }^{f f}: p<0.01$ after 48 h versus after $24 \mathrm{~h}$.

SPB has been proposed as a marker of lung damage by several groups evaluating patients with both lung and cardiac disease [10-14, 36, 38, 39]. De PASQuale et al. [18] showed that an acute pulmonary haemodynamic derangement, which usually develops in patients with exercise-induced cardiac ischaemia, induces a SPB increase; unfortunately, post-exercise SPB recovery was not assessed. Our study is the first in which mature and immature SPB changes were separately evaluated after a lung insult. We showed a rapid SPB increase after CPB (mean $\mathrm{CPB}$ duration $<2 \mathrm{~h}$ ) and a return to normal values almost within $24 \mathrm{~h}$. Therefore, SPB can be seen as a rapid and sensitive marker of lung distress. However, because the present is a pilot study performed in subjects free of previous lung disease and we have had no complications during surgery, we have no way to relate SPB changes in relation to the severity of lung damage. Furthermore, several studies $[10-14,36,38,39]$ have proposed SPB as a marker of lung injury and not as its cause, albeit the administration of exogenous surfactant has been proposed [40-42]. It should be noted that we have no established biological marker in the blood for acute lung injury. Indeed, only LDH has been occasionally used for this purpose but it is highly nonspecific and characterised by slow kinetics [43, 44]. Regardless we observed a weak correlation between greatest LDH and SPB changes. The increase of both immature and mature SPB forms after CPB, as well as the correlation of LDH and SBP changes, suggest that the observed increase of SPB forms in the blood is due to type II pneumocyte cell damage and not purely to SPB diffusion across the alveolarcapillary membrane. Indeed, the SPB immature form is usually intracellular and not found in the alveolar space. Both the mature and the immature form of SPB returned to normal values within $48 \mathrm{~h}$. However, by comparing the time behaviour of the two SPB forms we studied (figs 1 and 2), the immature SPB, which is a progenitor of the mature form, seems to remain high in the blood for a longer time than the mature form. It is possible, but totally unproved, that these differences are due to differences in clearance time.

Further studies are needed to confirm our observations in a larger population, to assess SPB changes after CABG in patients with previous lung and cardiac diseases, and to evaluate if $\mathrm{SPB}$ changes shortly after the beginning of $\mathrm{CPB}$ can predict the post-surgical clinical outcome of patients and, therefore, the need for post-surgical aggressive cardiorespiratory assistance. Moreover, the relationship of SPB changes during CABG with other surfactant derived proteins such as surfactant derived protein $\mathrm{D}$, the factors modifying the production of surfactant by alveolar type 2 cells, or the role of alveolar macrophages in the regulation of surfactant, all need to be evaluated. This is the first study where the mature SPB form was measured in the plasma. We showed that SPB forms in the plasma, as well as RAGE, are all sensitive and rapid markers of lung distress whose clinical relevance needs further investigation.

\section{SUPPORT STATEMENT}

This study was supported by Centro Cardiologico Monzino, IRCCS, Research Foundation 2009 (Milan, Italy).

\section{STATEMENT OF INTEREST}

None declared.

\section{REFERENCES}

1 Serrano AG, Perez-Gil J. Protein-lipid interactions and surface activity in the pulmonary surfactant system. Chem Phys Lipids 2006; 141: 105-118.

2 Notter R, ed. Lung Surfactants. Basic Science and Clinical Applications. New York, Marcel Dekker Inc., 2000.

3 Poulain FR, Allen L, Williams MC, et al. Effects of surfactant apolipoproteins on liposome structure: implications for tubular myelin formation. Am J Physiol 1992; 262: L730-L739.

4 Perez-Gil J. Structure of pulmonary surfactant membranes and films: the role of proteins and lipid-protein interactions. Biochim Biophys Acta 2008; 1778: 1676-1695.

5 Goerke J. Pulmonary surfactant: functions and molecular composition. Biochim Biophys Acta 1998; 1408: 79-89.

6 Weaver TE, Conkright JJ. Function of surfactant proteins B and C. Annu Rev Physiol 2001; 63: 555-578.

7 Hawgood S, Derrick M, Poulain F. Structure and properties of surfactant protein B. Biochim Biophys Acta 1998; 1408: 150-160. 
8 Weaver TE, Whitsett JA. Processing of hydrophobic pulmonary surfactant protein B in rat type II cells. Am J Physiol 1989; 257: L100-L108.

9 Weaver TE. Synthesis, processing and secretion of surfactant proteins B and C. Biochim Biophys Acta 1998; 1408: 173-179.

10 De Pasquale CG, Arnolda LF, Doyle IR, et al. Prolonged alveolocapillary barrier damage after acute cardiogenic pulmonary edema. Crit Care Med 2003; 31: 1060-1067.

11 Greene KE, Wright JR, Steinberg KP, et al. Serial changes in surfactant-associated proteins in lung and serum before and after onset of ARDS. Am J Respir Crit Care Med 1999; 160: 1843-1850.

12 Doyle IR, Bersten AD, Nicholas TE. Surfactant proteins-A and -B are elevated in plasma of patients with acute respiratory failure. Am J Respir Crit Care Med 1997; 156: 1217-1229.

13 Magri D, Brioschi M, Banfi C, et al. Circulating plasma surfactant protein type $\mathrm{B}$ as biological marker of alveolar-capillary barrier damage in chronic heart failure. Circ Heart Fail 2009; 2: 175-180.

14 De Pasquale CG, Arnolda LF, Doyle IR, et al. Plasma surfactant protein-B: a novel biomarker in chronic heart failure. Circulation 2004; 110: 1091-1096.

15 Agostoni P, Cattadori G, Guazzi M, et al. Cardiomegaly as a possible cause of lung dysfunction in patients with heart failure. Am Heart J 2000; 140: e24

16 Chua TP, Coats AJ. The lungs in chronic heart failure. Eur Heart J 1995; 16: 882-887.

17 Wasserman K, Zhang YY, Gitt A, et al. Lung function and exercise gas exchange in chronic heart failure. Circulation 1997; 96: 2221-2227.

18 De Pasquale CG, Arnolda LF, Doyle IR, et al. Circulating surfactant protein-B levels increase acutely in response to exercise-induced left ventricular dysfunction. Clin Exp Pharmacol Physiol 2005; 32: 622-627.

19 Cattadori G, Wasserman K, Meloni C, et al. Alveolar membrane conductance decreases as BNP increases during exercise in heart failure. Rationale for BNP in the evaluation of dyspnea. J Card Fail 2009; 15: 136-144.

20 Schmidt AM, Yan SD, Yan SF, et al. The multiligand receptor RAGE as a progression factor amplifying immune and inflammatory responses. J Clin Invest 2001; 108: 949-955.

21 Mukherjee TK, Mukhopadhyay S, Hoidal JR. Implication of receptor for advanced glycation end product (RAGE) in pulmonary health and pathophysiology. Respir Physiol Neurobiol 2008; 162: 210-215.

22 Calfee CS, Ware LB, Eisner MD, et al. Plasma receptor for advanced glycation end products and clinical outcomes in acute lung injury. Thorax 2008; 63: 1083-1089.

23 Grover FL. The Society of Thoracic Surgeons National Database: current status and future directions. Ann Thorac Surg 1999; 68: 367-373.

24 Hall RI, Smith MS, Rocker G. The systemic inflammatory response to cardiopulmonary bypass: pathophysiological, therapeutic, and pharmacological considerations. Anesth Analg 1997; 85: 766-782.

25 Messent M, Sullivan K, Keogh BF, et al. Adult respiratory distress syndrome following cardiopulmonary bypass: incidence and prediction. Anaesthesia 1992; 47: 267-268.

26 Butler J, Rocker GM, Westaby S. Inflammatory response to cardiopulmonary bypass. Ann Thorac Surg 1993; 55: 552-559.
27 Macnaughton PD, Braude S, Hunter DN, et al. Changes in lung function and pulmonary capillary permeability after cardiopulmonary bypass. Crit Care Med 1992; 20: 1289-1294.

28 Messent M, Sinclair DG, Quinlan GJ, et al. Pulmonary vascular permeability after cardiopulmonary bypass and its relationship to oxidative stress. Crit Care Med 1997; 25: 425-429.

29 Roques F, Nashef SA, Michel P, et al. Risk factors and outcome in European cardiac surgery: analysis of the EuroSCORE multinational database of 19030 patients. Eur J Cardiothorac Surg 1999; 15: 816-822.

30 Schagger H, von Jagow G. Tricine-sodium dodecyl sulfatepolyacrylamide gel electrophoresis for the separation of proteins in the range from 1 to $100 \mathrm{kDa}$. Anal Biochem 1987; 166: 368-379.

31 Bradford MM. A rapid and sensitive method for the quantitation of microgram quantities of protein utilizing the principle of protein-dye binding. Anal Biochem 1976; 72: 248-254.

32 Uchida T, Shirasawa M, Ware LB, et al. Receptor for advanced glycation end-products is a marker of type I cell injury in acute lung injury. Am J Respir Crit Care Med 2006; 173: 1008-1015.

33 Calfee CS, Budev MM, Matthay MA, et al. Plasma receptor for advanced glycation end-products predicts duration of ICU stay and mechanical ventilation in patients after lung transplantation. J Heart Lung Transplant 2007; 26: 675-680.

34 Brett J, Schmidt AM, Yan SD, et al. Survey of the distribution of a newly characterized receptor for advanced glycation end products in tissues. Am J Pathol 1993; 143: 1699-1712.

35 Tanji N, Markowitz GS, Fu C, et al. Expression of advanced glycation end products and their cellular receptor RAGE in diabetic nephropathy and nondiabetic renal disease. J Am Soc Nephrol 2000; 11: 1656-1666.

36 Friedrich B, Schmidt R, Reiss I, et al. Changes in biochemical and biophysical surfactant properties with cardiopulmonary bypass in children. Crit Care Med 2003; 31: 284-290.

37 LeVine AM, Lotze A, Stanley S, et al. Surfactant content in children with inflammatory lung disease. Crit Care Med 1996; 24: 1062-1067.

38 Koike T, Tsuchida M, Saitoh M, et al. Protective mechanism of ultrafiltration against cardiopulmonary bypass-induced lung injury. Transplant Proc 2009; 41: 3845-3848.

39 Goebel U, Siepe M, Mecklenburg A, et al. Reduced pulmonary inflammatory response during cardiopulmonary bypass: effects of combined pulmonary perfusion and carbon monoxide inhalation. Eur J Cardiothorac Surg 2008; 34: 1165-1172.

40 Enhorning G. Surfactant in airway disease. Chest 2008; 133: 975-980.

41 van Putte BP, Cobelens PM, van der Kaaij N, et al. Exogenous surfactant attenuation of ischemia-reperfusion injury in the lung through alteration of inflammatory and apoptotic factors. J Thorac Cardiovasc Surg 2009; 137: 824-828.

42 Kesecioglu J, Beale R, Stewart TE, et al. Exogenous natural surfactant for treatment of acute lung injury and the acute respiratory distress syndrome. Am J Respir Crit Care Med 2009; 180: 989-994.

43 Karaca P, Konuralp C, Enc Y, et al. Cardioprotective effect of aprotinin on myocardial ischemia/reperfusion injury during cardiopulmonary bypass. Circ J 2006; 70: 1432-1436.

44 Lorsomradee S, Cromheecke S, De Hert SG. Effects of sevoflurane on biomechanical markers of hepatic and renal dysfunction after coronary artery surgery. J Cardiothorac Vasc Anesth 2006; 20: 684-690. 